\title{
Wetland Use/Cover Changes and Local Perceptions in Uganda
}

\author{
Nelson Turyahabwe ${ }^{1}$, David Mwesigye Tumusiime ${ }^{2,3}$, Willy Kakuru ${ }^{4} \&$ Bernard Barasa $^{5}$ \\ ${ }^{1}$ Department of Extension and Innovation Studies, College of Agricultural and Environmental Sciences, \\ Makerere University, Kampala, Uganda \\ ${ }^{2}$ Department of Environmental Management, School of Forestry, Environmental and Geographical Sciences, \\ Makerere University, Kampala, Uganda \\ ${ }^{3}$ Department of International Environment and Development Studies (Noragric), Norwegian University of Life \\ Sciences (UMB), Aas, Norway \\ ${ }^{4}$ School of Forestry, Environmental and Geographical Sciences, Makerere University, Kampala, Uganda \\ ${ }^{5}$ Geographic Information Systems Centre, College of Engineering, Design, Art and Technology, Makerere \\ University, Kampala, Uganda \\ Correspondence: David Mwesigye Tumusiime, Department of Environmental Management, School of Forestry, \\ Environmental and Geographical Sciences, Makerere University, Kampala, Uganda. E-mail: \\ tumusid@yahoo.com
}

Received: June 15, 2013 Accepted: August 10, 2013 Online Published: September 2, 2013

doi:10.5539/sar.v2n4p95 URL: http://dx.doi.org/10.5539/sar.v2n4p95

\begin{abstract}
With increasing population, coupled with land shortage and weather variations, wetlands in Uganda have continued to face degradation due to mainly conversion for agricultural, industrial and settlement purposes. The objective of this study was to determine the spatial and temporal wetland use/cover changes and local perceptions attributed to these changes. The study utilized three sets of ortho-rectified and cloud free Landsat TM/ETM+/MSS temporal images (30 m) of 1986, 2000 and 2011. The classification procedures were carried out using an Integrated Land and Water Information System (ILWIS) software version 3.7. A wetland classification system for Uganda developed by the National Biomass Study, 2003 was adopted to describe the wetland use/cover types. The classified images were validated in a ground truthing exercise using Global Positioning System (GPS) to improve on the classification accuracy. Key informant interviews and focus group discussions were conducted with communities adjacent to the wetlands in each of three of the ten Ugandan agro-ecological zones to determine the underlying drivers of wetland use/cover changes, while household interviews generated information on local perceptions of the changes. Significant changes were mainly observed in wetland use/cover between 1986 and 2011. Major factors responsible for these changes were subsistence farming due to intensification of growing paddy rice in Kyoga plains, an influx of migrants who accessed wetlands for daily subsistence (livestock grazing) in South western farmlands and proximity to urban centres in the Lake Victoria Crescent. In all the sampled agro-ecological zones, increased crop farming in wetlands was due to changing opportunities created by existent large markets for wetland crops. Majority $(60 \%)$ of the local people perceived wetlands in their proximity to have undergone high degradation within the last 10 years, and to have declined in quantity and quality of vegetation, soil fertility and water levels. There was a noticeable variation across the sampled agro-ecological zones, with the highest proportion of local communities perceiving degradation being in Kyoga plains (76\%), followed by Lake Victoria crescent (63\%) and South-western farmlands (41\%). Locally perceived threats to wetlands were mainly from crop growing that accounted for $33 \%$ of the frequency of mentioned threats, collection of wetland resources (30\%), and prolonged floods and droughts (12\%). This study confirms the importance of economic opportunities from new market outlets and migration in its various forms as key factors in land use change, especially at timescales of a couple of decades.
\end{abstract}

Keywords: wetlands use/cover change, wetland degradation, spatial and temporal changes

\section{Introduction}

Wetlands are an important resource in sub-Saharan Africa that sustains rural livelihoods, particularly in areas with low or unpredictable rainfall, land scarcity or where uplands have poor soil characteristics and thus low potential for agriculture (Dixon, 2002; Dixon \& Wood, 2003; Halima \& Munishi, 2009; Rebelo et al., 2010). 
Wetlands play an important role in maintaining environmental quality, sustaining livelihoods and supporting biodiversity, which in turn support many of the regulating services that sustain agriculture (Falkenmark, Finlayson, \& Gordon, 2007). In drier regions, wetlands may be the only sites where people can get water, collect food and other basic supplies (Masiyandima, McCartney, \& Van Koppen 2004; Mwakubo \& Obare, 2009). In Uganda, it is estimated that over $50 \%$ of the total wetlands are under some form of human use to provide materials for domestic use but also generate some cash through collection and sale of roofing materials, fodder, water, raw materials for crafts, and from activities such as beekeeping, fishing, hunting and direct cultivation of food (Maclean, Tinch, Hassall, \& Boar, 2003). In Uganda, the wetland sector is estimated to employ at least 2.7 million people (nearly 10\% of the total population) (WMD, 2009; GoU, 2010). As a snapshot, wetland resources generate an estimated US\$432 per year to an average participating Ugandan household (Turyahabwe et al., 2013).

However, human use of wetlands is bound to alter wetland cover, if not well planned. A rapid change in wetland cover has been witnessed in Uganda over the recent decades; hastened by pressure for industrial expansion, especially in urban areas and the increasing annual population growth rate, estimated at $3.7 \%$ by 2002 (WMD, 2009). Consequently, Uganda has lost about $11,268 \mathrm{~km}^{2}$ of wetland, down from $37,575 \mathrm{~km}^{2}(15.6 \%$ of the nation's land area $\left(199810 \mathrm{~km}^{2}\right)$ in 1994 to about $26,308 \mathrm{~km}^{2}(10.9 \%)$ in 2009 , which represents a loss of $30 \%$ of the country's wetlands (WMD, 2009). Uganda is a party to the Ramsar Convention and local use of wetlands can thus be accorded international legitimacy only to the extent allowed within the framework of the Convention. Besides, there is a need to maintain a good balance between use and conservation of wetlands in view of promoting joint attainment of two of the most important contemporary societal goals -i.e. the first of the Millennium Development Goals (MDGs) - eradication of extreme poverty and hunger - and MDG 7 that seeks to promote environmental sustainability (UN, 2008). An assessment of the temporal patterns of changes in wetland cover can serve as a basis for development of mitigation strategies and contribute to achieving the two MDGs. The objective of this study was to determine the spatial and temporal wetland use/cover changes and local perceptions from the adjacent communities about effects of the change in Uganda. The base time period chosen is 1986, when the government restored law and order in the institutions for the governance of most natural resources including wetlands, extending to 2011 when this study was conducted.

\section{Study Area and Methods}

\subsection{Study Area}

Three of the ten Ugandan agro-ecological zones (Kyoga plains, South western farmlands, and Lake Victoria Crescent) were randomly selected for the study (Figure 1). Wetlands in each of the three zones were categorised into strata based on a national system for wetland characterization, which identifies four ecological and socio-economic factors. The four factors used included agro-ecological factors of a wetland system, population density, farming system, and level of food security (MWLE, 2003). From the strata, random selection was used to sample two wetlands from each of the agro-ecological zones giving a total of six study sites.

- Opeta and Gogonyo wetlands in Pallisa district and Limoto wetland in Kibuku district were selected to represent Kyoga plains. This zone is characterized by small-scale subsistence agriculture, mainly of annual crops, some pastoralism and a high level of food insecurity. The human population density is moderate at 252 persons per $\mathrm{km}^{2}$. The annual rainfall range is $900-1500 \mathrm{~mm}$, and the vegetation is mainly composed of savanna species (Pallisa District, 2004).

- Lake Nakivale in Isingiro district and Rucece wetland in Mbarara district were selected to represent the South western farmlands agro-ecological zone; with a moderate level of food security and moderate population density of about 247 persons per $\mathrm{km}^{2}$. Annual rainfall averages about $957 \mathrm{~mm}$ and the vegetation is largely a combination of bush lands and short grass, suitable for animal grazing.

- Munyere and Mabamba Bay wetlands in Wakiso district were selected to represent the Lake Victoria Crescent, a high population density zone $\left(484\right.$ persons per $\mathrm{km}^{2}$ ), with a medium level of food security (WFP 2009). The mean annual rainfall in the Lake Victoria Crescent is about $1320 \mathrm{~mm}$. The vegetation varies from medium altitude evergreen forest, through medium altitude moist semi-deciduous forests, savannas and swamps (Directorate of Water Development, 2010). 


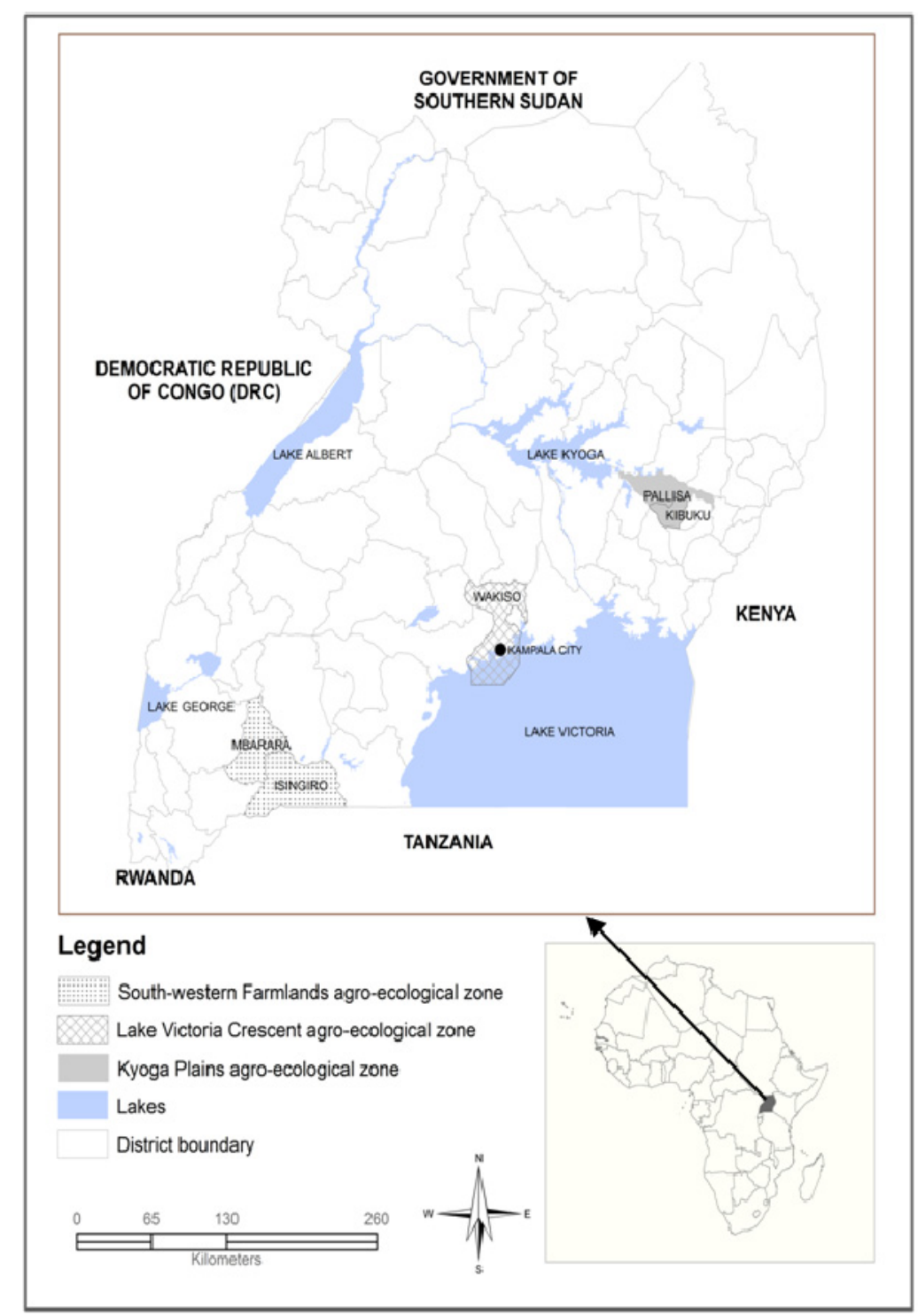

Figure 1. Location map of sample wetlands in Uganda

\subsection{Data Collection and Analysis}

\subsubsection{Quantification of Wetland Use/Cover Changes}

The study utilized three sets of ortho-rectified and cloud free Landsat TM/ETM+/MSS temporal images (30 m) of 1986, 2000 and 2011. The study takes 1986 as a base year because it is the time when the National Resistance Movement government came into power and started reforming institutions for governing natural resources, including wetlands. As part of policy reforms, the government also put a ban on large scale wetland drainage, to enable the process of formulation of a National Wetlands Conservation and Management policy to take place. The images were classified using a manual classification approach for information extraction. Inaccurate wetland information could be extracted if both unsupervised and supervised classifications approaches were applied. This is due to the non-homogeneity of vegetation types in and around Uganda's wetland systems. The classification procedures were carried out using an Integrated Land and Water Information System (ILWIS) software version 3.7. To describe the wetland use/cover types, the study adopted a wetland classification system for Uganda developed by the National Biomass Study of 2003 (MWLE, 2003). Seven (7) wetland cover types were thus identified (Table 1). 
Table 1. Description of wetland use/cover types in the three agro-ecological zones

\begin{tabular}{ll}
\hline Wetland use/cover type & Description \\
\hline Seasonal woodlands & Included trees and shrubs (average height $>4 \mathrm{~m}$ ) \\
Seasonal bushes and thicket & Bush, thickets, scrubs (average height $<4 \mathrm{~m}$ ) \\
Grasslands (permanent and seasonal) & Rangelands, pasturelands, open savanna with scattered trees \\
Permanent small scale farming & $\begin{array}{l}\text { Wetland sections under cultivation throughout the year and } \\
\text { includes mixed farmlands, small/large holdings in use or }\end{array}$ \\
& $\begin{array}{l}\text { recently used } \\
\text { Seasonal small scale farming }\end{array}$ \\
Wetland sections under cultivation on a seasonal basis and also \\
comprise of mixed farmlands, small/large holdings in use or \\
recently used \\
Papyrus & $\begin{array}{l}\text { Water logged sections with papyrus vegetation and other } \\
\text { sedges and Phragmites spp. } \\
\text { Open water }\end{array}$ \\
\hline
\end{tabular}

The classified images were validated in a ground truthing exercise that involved use of a Global Positioning System (GPS) to collect geographic coordinates for each wetland cover type. The validation exercise improved the image classification accuracy. Three (3) focus group discussions were also conducted in the three agro-ecological sampled zones, each comprising of 6-12 local residents. Participants were purposefully selected basing on their knowledge on wetland use/cover changes, duration of residence in the selected adjacent wetlands and utilisation of wetland products/resources. Key informant interviews were held with staff from the Districts Natural Resources and Production Departments and the National Agricultural Advisory Services (NAADS) section of the respective District and Sub county Local Governments.

\subsubsection{Local Perceptions of Wetlands Use/Cover Change}

To examine local perceptions of change in wetland use/cover, we administered semi-structured interviews among two hundred forty seven (247) households randomly selected from within a $5 \mathrm{~km}$ distance from the boundaries of the sampled wetlands. This included 81 households selected from the wetlands in the Lake Victoria crescent, 82 from South western farmlands, and another 84 from Kyoga plains. The non-uniformity in the total number of local residents interviewed was due to the sparse settlements and limited access to settled areas in the sampled zones. Within the selected households, the survey targeted household heads, but for practical reasons in the few instances where these were not at home, the most knowledgeable and senior of the adults present was interviewed. Before conducting each interview, the purpose of the study was explained to each respondent as purely scientific and academic. Since some respondents accessed wetlands illegally, it was emphasised that our study had no legal implications whatsoever. Respondents were in addition assured of anonymity and confidentiality and that participation was purely voluntary. Given the human difficulty in recalling events deep in the past, local perception of wetland use/cover change was limited to the last 10 years and the change explicitly classified by inquiring if the adjacent wetland(s) had been degraded over the last 10 years. All interviews were carried out in a common local language for each study site. The survey tools were pre-tested in areas that were not part of the sample. This allowed the interviewers familiarity with the tool, but also application and review of the method.

\section{Results and Discussion}

\subsection{Spatial and Temporal changes in Wetland Use/Cover}

For the period 1986, 2000 and 2011, open water was the most predominant wetland cover type within the Lake Victoria Crescent, papyrus in the Kyoga plains and seasonal bushes and thickets in the South western farmlands (Figure 2, Table 2). However, there have been more significant changes in other wetland use/cover types between 1986 and 2011 in the sampled agro-ecological zones. These changes are mainly seen in significant losses of land experienced in seasonal woodlands, bushes and thickets. The continued loss of seasonal woodlands, bushes and thickets to other wetland use/cover types was mainly responsible for the large differences between 1986-2000 and 1986-2011 in the total area for zones 2 and 3.

The three agro-ecological zones support different land cover types, but a number of general observations were made. There were changes in wetland use/cover between 1986 and 2011, with the magnitude of changes varying 
between agro-ecological zones (Figure 1, Table 2). The changes were seen in percentage gain or loss of land by wetland use/cover types. Between 1986 and 2000, the most pronounced changes were in the Lake Victoria crescent and south western farmlands (Figure 3). In both areas, the percentage changes related to subsistence farming; $950 \%$ increment in coverage by permanent subsistence farming and $1167 \%$ in seasonal subsistence farming in the former. In the latter, coverage by seasonal subsistence farming increased by $767 \%$.

Increments in wetland areas under subsistence farming in the Lake Victoria Crescent emanate from proximity to urban areas of Kampala (the capital city), Wakiso, Entebbe, Mukono and Jinja (formerly, an industrial city). Urban poor people frequently depend on wetlands for food production, but also the populations in the urban areas create markets for wetland produce, and thus encourage wetland use (Tejuoso, 2006). Changes in the South western farmlands can be attributed to an influx of refugees from the Democratic Republic of Congo, Rwanda, Eritrea, Ethiopia, Kenya, Sudan, Burundi, and Somalia. These are refugees who have fled their respective countries following internal instabilities including the 1994 Rwanda genocide and civil wars in other countries. These refugees are settled under the self reliance strategy of the United Nations High Commission for Refugees (UNHCR) and are thus expected to be self reliant (in terms of food, shelter and income), but not to depend on hand outs. This way they end up turning to wetlands for subsistence, since these are frequently viewed as common or open access resources. Increased permanent and subsistence farming in the Kyoga plains is mainly from intensified paddy rice growing in wetland areas.

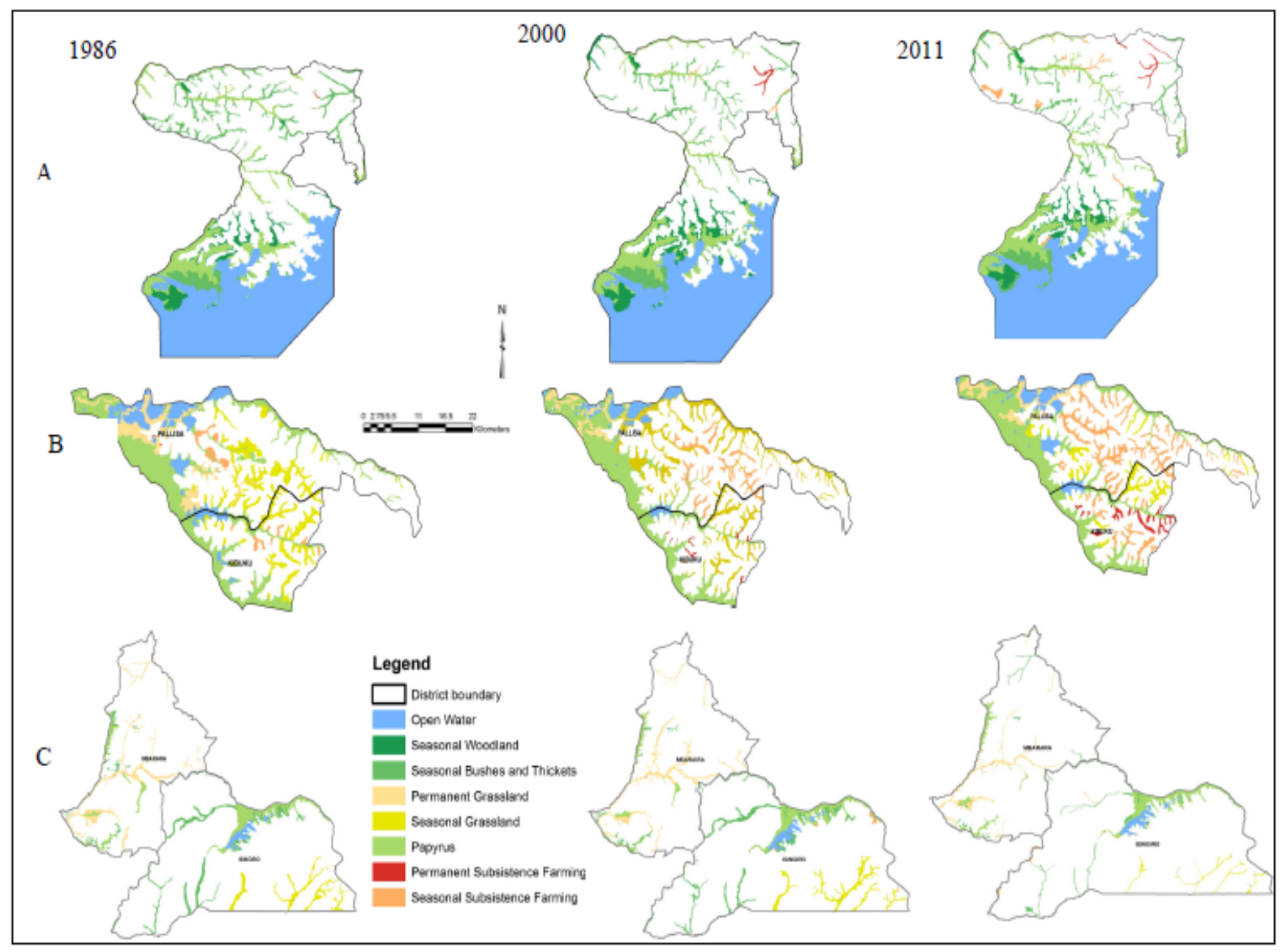

Figure 2. Wetland cover change for years 1986, 2000 and 2011 (A= Lake Victoria Crescent, B= Kyoga plains, $\mathrm{C}=$ South western farmlands) 
Table 2. The area per wetland use type for years 1986, 2000 and 2011

\begin{tabular}{|c|c|c|c|c|c|c|c|c|c|c|c|c|c|}
\hline \multirow{3}{*}{$\begin{array}{l}\text { Agro- } \\
\text { ecological } \\
\text { zone }\end{array}$} & \multirow{3}{*}{ Wetland use/cover type } & \multicolumn{6}{|c|}{ Total wetland coverage } & \multicolumn{6}{|c|}{ Wetland use/cover change } \\
\hline & & \multicolumn{2}{|l|}{1986} & \multicolumn{2}{|c|}{2000} & \multicolumn{2}{|c|}{2011} & \multicolumn{2}{|c|}{$1986-2000$} & \multicolumn{2}{|c|}{$2000-2011$} & \multicolumn{2}{|c|}{$1986-2011$} \\
\hline & & (Sq. km) & $\%$ & (Sq. km) & $\%$ & (Sq. km) & $\%$ & (Sq. km) & $\%$ & (Sq. km) & $\%$ & (Sq. km) & $\%$ \\
\hline 1 & Open water & 875.1 & 66 & 875.6 & 65.9 & 870.8 & 64.9 & 0.5 & 0.1 & -4.8 & -0.5 & -4.3 & -0.5 \\
\hline 1 & Seasonal woodlands & 75.7 & 5.7 & 116.8 & 8.8 & 85.7 & 6.4 & 41.1 & 54.3 & -31.1 & -26.6 & 10 & 13.2 \\
\hline 1 & Seasonal bushes and thickets & 155.2 & 11.7 & 116.2 & 8.7 & 149.4 & 11.1 & -39 & -25.1 & 33.2 & 28.6 & -5.8 & -3.7 \\
\hline 1 & Papyrus & 218.1 & 16.5 & 210.1 & 15.8 & 207.4 & 15.4 & -8 & -3.7 & -2.7 & -1.3 & -10.7 & -4.9 \\
\hline 1 & Permanent subsistence farming & 0.6 & 0 & 6.3 & 0.5 & 8.2 & 0.6 & 5.7 & 950 & 1.9 & 30.2 & 7.6 & 1266.7 \\
\hline 1 & Seasonal subsistence farming & 0.3 & 0 & 3.8 & 0.3 & 21.1 & 1.6 & 3.5 & 1166.7 & 17.3 & 455.3 & 20.8 & 6933.3 \\
\hline 2 & Open water & 121.4 & 14.2 & 62.7 & 10.3 & 80.3 & 11.6 & -58.7 & -48.4 & 17.6 & 28.1 & -41.1 & -33.9 \\
\hline 2 & Permanent grasslands & 80.5 & 9.4 & 41.6 & 6.8 & 52.1 & 7.6 & -38.9 & -48.3 & 10.5 & 25.2 & -28.4 & -35.3 \\
\hline 2 & Seasonal grasslands & 210.8 & 24.6 & 174.8 & 28.6 & 72.6 & 10.5 & -36 & -17.1 & -102.2 & -58.5 & -138.2 & -65.6 \\
\hline 2 & Papyrus & 409.1 & 47.7 & 278.5 & 45.6 & 321.1 & 46.6 & -130.6 & -31.9 & 42.6 & 15.3 & -88 & -21.5 \\
\hline 2 & Permanent subsistence farming & 1.7 & 0.2 & 5.4 & 0.9 & 23.3 & 3.4 & 3.7 & 217.6 & 17.9 & 331.5 & 21.6 & 1270.6 \\
\hline 2 & Seasonal subsistence farming & 34.4 & 4 & 47.9 & 7.8 & 140.1 & 20.3 & 13.5 & 39.2 & 92.2 & 192.5 & 105.7 & 307.3 \\
\hline 3 & Open water & 33.7 & 7.1 & 37.3 & 8 & 32.2 & 11.1 & 3.6 & 10.7 & -5.1 & -13.7 & -1.5 & -4.5 \\
\hline 3 & Seasonal bushes and thickets & 127.5 & 26.9 & 117.3 & 25.1 & 49.5 & 17 & -10.2 & -8 & -67.8 & -57.8 & -78 & -61.2 \\
\hline 3 & Permanent grasslands & 101.2 & 21.4 & 93.7 & 20.1 & 55.2 & 19 & -7.5 & -7.4 & -38.5 & -41.1 & -46 & -45.5 \\
\hline 3 & Seasonal grassland & 68.5 & 14.5 & 74.5 & 16 & 17.6 & 6.1 & 6 & 8.8 & -56.9 & -76.4 & -50.9 & -74.3 \\
\hline 3 & Papyrus & 142.2 & 30 & 136.3 & 29.2 & 127.1 & 43.7 & -5.9 & -4.1 & -9.2 & -6.7 & -15.1 & -10.6 \\
\hline 3 & Seasonal subsistence farming & 0.9 & 0.2 & 7.8 & 1.7 & 9.3 & 3.2 & 6.9 & 766.7 & 1.5 & 19.2 & 8.4 & 933.3 \\
\hline
\end{tabular}

$1=$ Lake Victoria crescent, 2 = Kyoga plains, and 3 = south western farmlands

*** The percentages under Total wetland coverage are in terms of total area for the zone whereas those for the change are in terms of the initial area in 1986 for the cover type. The missing wetland use/cover types in other zones are due to the different lacustrine bound vegetation and human interference.

Agro-ecological zone 1 had the highest total land area (1325 sq.km), followed by zone 2 with 857.9 sq.km and lastly zone 3 with 474 sq.km. 


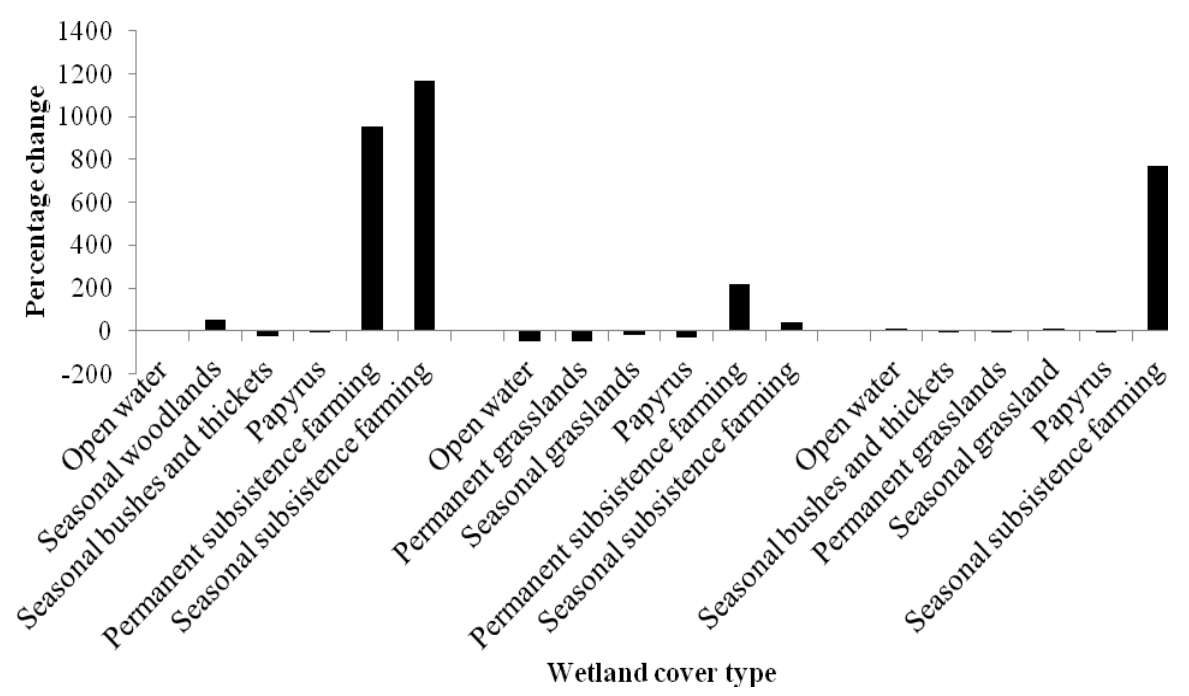

Figure 3. Trends in wetland cover changes between 1986 and 2000 (Lake Victoria Crescent, Kyoga plains, south western farmlands)

Between 2000 and 2011 subsistence farming remained the dominant form of land use accounting for wetland change, in the three zones (Figure 4). In the Lake Victoria Crescent, reasons for increment are the same as between 1986 and 2000, but the slower rate of increment can be attributed to a ban by government on large-scale wetland drainage and improved regulation on wetland use following the establishment of a national wetlands programme in 1989. The programme sought to develop a National Wetlands Conservation and Management Policy to guide wetland users and the government on best practices. As a result, a National wetland conservation and management policy was enacted in 1995 and provisions on wetland use were also included in important legislations such as the 1995 Constitution of the Republic of Uganda, 1995 National Environment Statute that established a National Environmental Management Authority, 1995 Water Statute, the 1997 Local Government Act (GoU, 1997). In the Kyoga plains, increments are because small scale farmers took to paddy rice growing in that period (NEMA, 2008). The most pronounced change in the south western farmlands was a decline in seasonal bushes and thickets, permanent grasslands and seasonal grasslands due to pressure from livestock grazing by pastoralists in the area and the collection of grass for mulching banana plantations. The zone is a major producer of bananas in Uganda.

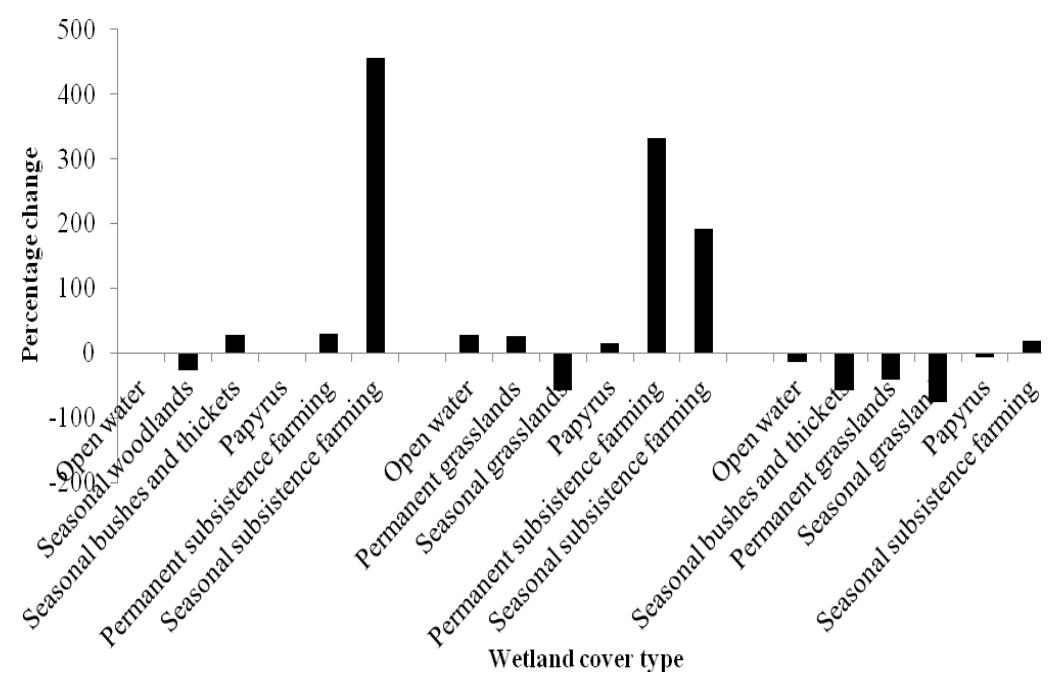

Figure 4. Percentage wetland cover changes between 2000 and 2011 (Lake Victoria crescent, Kyoga plains, south western farmlands) 
The trend for increasing conversion of wetlands for subsistence farming is clearer when 2011 coverage is compared with that of 1986 particularly in the Lake Victoria crescent and Kyoga plains (Figure 5). Subsistence farming is the main source of livelihood for rural households in Uganda. In Turyahabwe et al.'s (2013) recent study among households in the same zones, over $80 \%$ of the respondents reported wetlands to contribute enormously to household food security partly through use for subsistence production. This is not unique to Uganda and other studies have reported an increasingly central role of wetlands in securing livelihoods in rural areas of developing countries by helping households to cope with vagaries of climate and weather changes and declining soil fertilty (e.g. see McCartney and van Koppen, 2004; Thompson et al. 2010). Wetlands are also a main resource that the urban poor, as in the case of the Lake Victoria crescent, draw upon to meet own subsistence (Tejuoso, 2006). Reduced wetland cover changes in the Kyoga plains are attributable to the gradual substitution of traditional cropping systems with paddy rice and vegetable growing, both of which need wetlands. The prices of both rice and vegetables have been increasing and in the process lured more households into rice and vegetable production and more land is sought from wetlands to meet this growing need (NEMA, 2008). Reports from the focus group discussions in the Kyoga plains indicated that most farmers have resorted to use of wetlands for crop farming due to declined fertility of the upland agricultural areas.

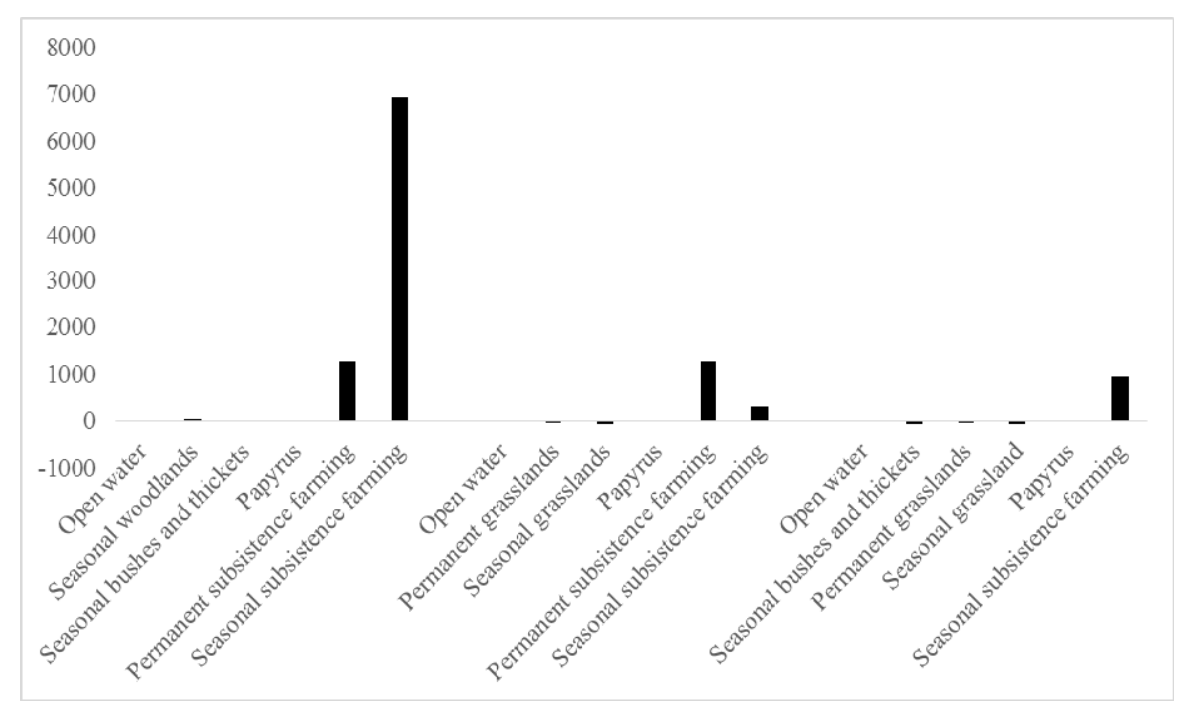

Figure 5. Percentage wetland cover changes between 1986 and 2011 (Lake Victoria crescent, Kyoga plains, south western farmlands)

\subsection{Local Perceptions of Wetland Cover Change}

Up to $60 \%$ of the respondents perceived wetlands in their proximity to have undergone degradation within the last 10 years. However, there was some variation across agro-ecological zones in the extent to which local people viewed their wetlands as degraded. The highest proportion perceiving degradation was in Kyoga plains (76\%); followed by Lake Victoria crescent (63\%) and the least proportion in South western farmlands (41\%), where a much larger proportion of the respondents $(56 \%)$ explicitly reported perceiving no degradation of the wetland(s) in their vicinity (Figure 6). Local perceptions seem to be consistent with the trends recorded during this study for the spatial and temporal analyses of wetland change from satellite imagery. Residents of Kyoga plains are more likely to perceive wetland degradation because wetland change is a recent phenomenon following the gradual substitution of traditional cropping systems with paddy rice and vegetable growing, which was reported during the FGDs to have intensified during the 1980s. On the other hand, a smaller percentage of residents of South western farmlands perceived degradation of wetlands in their proximity possibly because many are immigrants and relatively recent arrivals with limited comprehension of the temporal changes. 


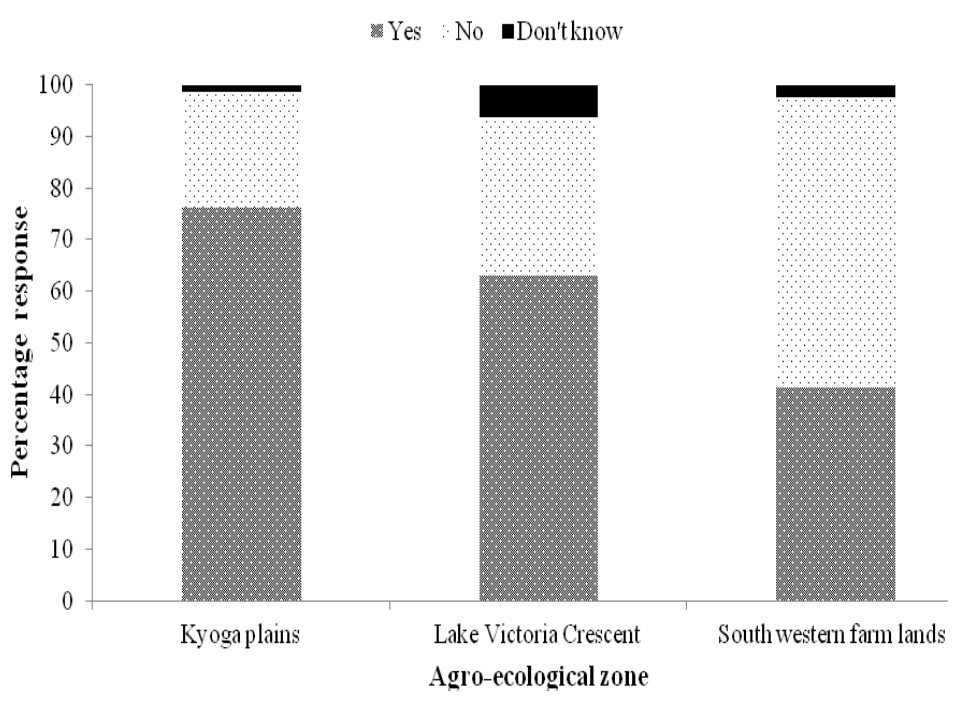

Figure 6. Local perception of degradation of wetlands in Uganda

The most frequent signs or features perceived to indicate wetland degradation were decline in quantity and quality of vegetation $(24 \%)$, reduced water level $(22 \%)$ and local farmers cultivating close to the boundaries of the wetlands (13\%) (Table 3$)$.

Table 3. Signs or features perceived to indicate degraded wetlands in Uganda

\begin{tabular}{lc}
\hline Sign of wetland change & Percentage \\
\hline Poor/ reduced vegetation & 25 \\
Reduction in water level & 22 \\
Cultivation closer to the wetlands & 13 \\
Drainage channels in wetland & 10 \\
cutting trees or deforestation & 10 \\
Burning of swamps & 7 \\
Reduced fish & 7 \\
Reduced productivity of wetland & 3 \\
Open sand pits & 2 \\
Reduced wetland animals & 2 \\
\hline
\end{tabular}

Locally perceived threats to wetlands included on one hand natural events in the form of floods and droughts $(12 \%)$, and on the other human activities including collection of wetland resources $(30 \%)$ and use of wetland resources where crop growing featured prominently accounting for $33 \%$ of the frequency of mentioned threats (Table 4). 
Table 4. Locally perceived threats to wetlands in Uganda

\begin{tabular}{lc}
\hline Threat & Percentage \\
\hline Natural hazards & 6 \\
Drought & 6 \\
Floods & \\
Collection of wetland resources & 7 \\
Trees & 6 \\
Fodder & 5 \\
Fish & 6 \\
Sand or clay & 3 \\
Thatching & 1 \\
Bushmeat & 1 \\
Firewood & \\
Use of wetland & 21 \\
Growing crops in wetlands & 12 \\
Growing crops close to wetlands & 10 \\
Drainage channels & 9 \\
Bush burning & 2 \\
Construction work & 2 \\
Poor farming methods &
\end{tabular}

Consumptive human use of wetlands dominates the list of threats identified by the local people. During the focus group discussions, respondents indicated that crop growing in wetlands had led to drying of water springs and wells in adjacent areas. However, the respondents reported that no deliberate efforts have been put in place to promote technological innovations to minimize the impacts from crop growing.

\section{Conclusion}

This study has provided data to show that there have been significant changes in wetland cover in Uganda between 1986 and 2011. A major factor responsible for these changes was subsistence farming mainly due to intensification of growing of paddy rice in Kyoga plains, an influx of migrants who access wetlands for daily subsistence in South western farmlands and proximity to urban centres in the Lake Victoria Crescent. In all the agro-ecological zones, increased crop farming in wetlands was due to changing opportunities created by markets for wetland produce. This study thus supports earlier observation that eeconomic opportunities resulting from new market outlets are a key factor in land use change (Hecht, 1985; Angelsen, 1995; Imbernon, 1999; Tejuoso, 2006). The study also confirmed that migration in its various forms is the most important demographic factor causing land-use change, especially at timescales of a couple of decades (Angelsen \& Kaimowitz, 1999; Geist, 2002). The study found out that wetland drainage has led to socio-economic consequences of losing water supply sources such as springs and wells, which was mainly reported in the Kyoga plains.

\section{Acknowledgement}

The authors would like to thank International Development Research Centre (IDRC) for funding this study.

\section{References}

Angelsen, A. (1995). Shifting cultivation and "deforestation": a study from Indonesia. World Development. 23(10), 1713-29. http://dx.doi.org/10.1016/0305-750X(95)00070-S

Angelsen, A., \& Kaimowitz, D. (1999). Rethinking the causes of deforestation: Lessons from economic models. The World Bank Research Observer, 14(1), 73-98. http://dx.doi.org/10.1093/wbro/14.1.73

Dixon, A. B. (2002). The hydrological impacts and sustainability of wetland drainage cultivation in Illubabor, Ethiopia. Land Degradation and Development, 13, 17-31. http://dx.doi.org/10.1002/ldr.479 
Dixon, A. B., \& Wood, A. P. (2003). Wetland cultivation and hydrological management in eastern Africa: matching community and hydrological needs through sustainable wetland use. Natural Resources Forum, 27, 117-129. http://dx.doi.org/10.1111/1477-8947.00047

Falkenmark, M., Finlayson, C. M., \& Gordon, L. J. (2007). Agriculture, water and ecosystems: Avoiding the costs of going too far. In D. Molden (Ed.), Water for Food, Water for Life: Comprehensive Assessment of Water Management in Agriculture.

Geist, H. J., \& Lambin, E. F. (2002). Proximate causes and underlying driving forces of tropical deforestation. BioScience, 52(2), 143-50. http://dx.doi.org/10.1641/0006-3568(2002)052[0143:PCAUDF]2.0.CO;2

GoU. (1997). The local government act. Entebbe, Government printer: Government of Uganda.

GoU. (2010). The Republic of Uganda: National Development Plan for Uganda. 2010/11-2014/15. National Planning Authority (NPA), Government of Uganda, Kampala.

Halima, K., \& Munishi, K. T. P. (2009). Contribution of wetlands to household income and food security in the Nyumba Ya Mungu wetland system, northern Tanzania. Tanzania Journal of Forestry and Nature Conservation, 79(2), 99-108.

Hecht, S. B. (1985). Environment, development and politics: capital accumulation and the livestock sector in eastern Amazonia. World Development, 13(6), 663-84. http://dx.doi.org/10.1016/0305-750X(85)90114-7

Imbernon, J. (1999). Pattern and development of land-use changes in the Kenyan highlands since the 1950s. Agriculture, Ecosystems \& Environment, 76(1), 67-73. http://dx.doi.org/10.1016/S0167-8809(99)00061-4

Masiyandima, M., McCartney, M. P., \& Van Koppen, B. (2004). Wetland contributions to livelihoods in Zambia. FAO Netherlands Partnership Program: Sustainable Development and Management of Wetlands.

McCartney, M. P., \& van Koppen, B. (2004). Sustainable Development and Management of Wetlands. Wetlands contributions to livelihoods in United Republic of Tanzania. IUCN, IWMI, FAO, FAO-Netherlands Partnership Programme, Rome, Italy.

Mwakubo, S. M., \& Obare, G. A. (2009). Vulnerability, livelihood assets and institutional dynamics in the management of wetlands in Lake Victoria watershed basin. Wetland Ecology and Management, 17, 613-626. http://dx.doi.org/10.1007/s11273-009-9138-6

MWLE. (2003). National biomass study technical report. Ministry of Water, Lands and Environment, Government of Uganda, Kampala.

NEMA. (2008). Pilot Integrated Environment Assessment of the Lake Kyoga Catchment Area. National Environment Management Authority (NEMA), Kampala.

Pallisa District. (2004). District State of Environment Report. Government of Uganda, Kampala.

Rebelo, L. M., McCartney, M. P., \& Finlayson, C. M. (2010). Wetlands of Sub-Saharan Africa: distribution and contribution of agriculture to livelihoods. Wetlands Ecology and Management, 18, 557-572. http://dx.doi.org/10.1007/s11273-009-9142-x

Tejuoso, O. J. (2006). Wetland uses/dynamics for agricultural purposes and its health implications in lower Ogun river basin, Lagos, Nigeria. Technical report submitted to the International Development Research Centre (IDRC).

Thompson, H. E., Berrang-Ford, L., \& Ford, J. D. (2010). Climate change and food security in Sub-Saharan Africa: A systematic literature review. Sustainability, 2, 2719-2733. http://dx.doi.org/10.3390/su2082719

Turyahabwe, N., Kakuru, W., Tweheyo, M., \& Tumusiime, D. M. (2013). Contribution of wetland resources to household food security in Uganda. Agriculture and Food Security, 2(5), 2-12.

UN. (2008). Millenium Development Goals (MDGs). New York, USA: United Nations.

WFP. (2009). Comprehensive Food Security and Vulnerability Analysis (CFSVA) in Uganda. United Nations World Food Programme.

WMD. (2009). Mapping a better future: How spatial analysis can benefit Wetlands and reduce poverty in Uganda. Wetlands Management Department, Ministry of Water and Environment.

\section{Copyrights}

Copyright for this article is retained by the author(s), with first publication rights granted to the journal.

This is an open-access article distributed under the terms and conditions of the Creative Commons Attribution license (http://creativecommons.org/licenses/by/3.0/). 